\title{
Probing the Differences Caused by Cognitive Variables on LET Performance: An Embedded Mixed Method Study
}

\author{
Michael B. Cahapay \\ College of Education, Mindanao State University, \\ Fatima, General Santos City, South Cotabato, Philippines \\ http://orcid.org/0000-0002-0588-0022
}

\begin{abstract}
The purpose of this study is to probe the differences caused by selected cognitive variables such as entrance test scores (ETS) and grade point average (GPA) on the performance of the graduates in the Licensure Examination for Teachers (LET). It entailed a causalcomparative embedded mixed method research design. The study followed a cohort of 42 purposively sampled graduates of Bachelor of Elementary Education (BEEd), College of Education (CoEd), Mindanao State University (MSU), General Santos City (GSC). Descriptive statistics and inferential statistics were used to determine the differences in the LET performance when grouped according to arbitrary categories of the cognitive variables. A presentation of case narratives and thematic analysis was further used to explore the significant differences. The result disclosed that the ETS of the graduates grouped as passed and conditional cause a significant difference in the LET performance. It further uncovered that the GPA of the graduates grouped as high, average, and low causes a significant difference in the LET performance. The qualitative probes revealed themes such as access to review materials, metacognitive strategies, motivational experiences, and efficacy to succeed. These themes provide explanatory context to the differences in the performance of the graduates in the LET. The implications are further discussed in the study.
\end{abstract}

Keywords: entrance test scores; grade point average; Licensure Examination for Teachers; embedded mixed method

\section{Introduction}

The expectation of a high passing rate in the teacher licensure examination intends to ensure a base of competence for public protection (Pitter, Lanham, \& McGalliard 1997). It also holds teacher education institutions accountable for their programs (Knowles, Plake, Robinson, \& Mitchell, 2001). Thus, success in the teacher licensure examination serves two purposes. It does not only indicate that the person holding the license possesses the entry capacity to perform the 
duties covered by professional teaching, but also confirm the quality of a teacher education program.

The Republic Act No. 7836, also known as the Philippine Teachers Professionalization Act of 1994, mandated the promotion, development, professionalization, supervision, and regulation of the practice of teaching in the Philippines. Recognizing the significant role of the teachers in the process of building solid foundations of the nation through education, a primary provision of the said law is the conduct of the LET. It is a measure to ensure the quality of the teachers and teacher education institutions in the entire country. Thus, teacher education graduates are required to pass the licensure examination before they can be allowed to practice as professional teachers in the field.

A cumulative record of the national passing rates in the LET elementary level released by the Commission on Higher Education, however, indicates an erratic trend over the past few years. The national passing rate was documented at $31.18 \%$ in 2013 . The figure went higher at $35.74 \%$ in 2014 . However, it did not drastically improve in the following years with $31.36 \%$ in $2015,30.18 \%$ in 2016 , and $26.33 \%$ in 2017 respectively. This trend suggests that a large majority of elementary teacher education institutions in the country produce a considerable number of graduates who are not qualified to practice in the field after graduation.

This matter appears to be unique in the BEEd, CoEd, MSU, GSC. The passing rates for its first-time takers were recorded as follow: $75.91 \%$ in $2013 ; 71.14 \%$ in $2014 ; 68.35 \%$ in $2015 ; 69.51 \%$ in 2016 ; and $78.98 \%$ in 2017 . While these numbers signify a performance that is above the national passing rate, the department administration voiced concern about the annual cohort of graduates below the passing rate. This cohort can be traced back to some disadvantaged students admitted to the program (J. Pantao, personal communication, October 24, 2017). Though differences in the cognitive abilities seem to be the meat of the department discussions on this issue, there appear to be other covert perspectives that need to be illuminated.

A vast body of recent scholarly works (e.g. Hegman, Roscoe, \& Statler, 2015; Bennett, Bormann, Lovan, \& Cobb, 2016; Rabanal, 2016; Cameron, MacKeigan, Mitsakakis, \& Pugsley, 2017; Huhn \& Parrott, 2017; Labastilla, 2017; Meiners \& Rush, 2017; Bellen, Abela, R., \& Truya, 2018; Havrilla, Zbegner, \& Victor, 2018; Kume \& Horbacewicz, 2018; Wolden, 2018) has continued the tradition of determining the predictive power of different cognitive variables on the licensure examination performance of the graduates. However, a closer look at these studies reveals a scarcity of effort that attempts to further probe the differences caused by the cognitive variables on the licensure examination performance.

The present inquiry retrospectively suggests that, when looking at the LET performance of the graduates, it is important not only to determine the differences caused by selected cognitive variables such as ETS and GPA. It should be underscored that performance as a human construct is a combination of an array of confounding systems and interactions accumulated through time. Drawing upon the notions of ecological systems (Bronfenbrenner, 1979), this 
study attempts to address an essential need to explore the themes that contextually underpin the differences in the licensure examination performance of the graduates.

Thus, the general purpose of this study is to probe the differences caused by selected cognitive variables on the LET performance of BEEd graduates. It specifically answered the following questions:

1. What differences in the LET performance of the passed and conditional groups are caused by the ETS?

2. What differences in the LET performance of the low, average, and high groups are caused by the GPA?

3. What themes emerge when the differences in the LET performance are placed in a broader explanatory context?

\section{Literature Review}

The ecological systems theory pioneered by Bronfenbrenner (1979) explores the biological, emotional, social, and cultural aspects that influence human development. It calls for the attention of scholars on the process of human development as being fashioned by the interaction between the individuals and their environment. This theory posits that interactions, institutions, and systems have a profound impact on the development of people.

The ecological systems have been likewise used over the years to study human behavior and performance (e.g. Darling, 2007; Tzeng \& Gau, 2012; Culpepper \& Killion, 2016; Rojas-Drummond, 2016; Walker, 2016; Eriksson, Ghazinour, \& Hammarstrom, 2018). The theory has encouraged valid studies in contextual variations. Thus, it can be redefined in this research to determine the differences caused by selected cognitive variables and explain the unique themes that underlie the performance of the graduates.

There is plentiful evidence that proves how admission policies and school outcomes play a role in the success in the licensure examinations. A review of relevant researches conducted mostly in the domain of health sciences (Cook, Engelhard, Landry, \& McCallum, 2015; Gresham, Thompson, Luedtke-Hoffman, \& Tietze, 2015; Gullo, McCarthy, Shapiro, \& Miller, 2015; Kidder, 2015; Moniyung, 2015; Ingrassia, 2016; Bayliss, Thomas, \& Eifert-Mangine, 2017; Huhn \& Parrott, 2017; Kaddoura, Flint, Van Dyke, Yang, \& Chiang, 2017; Meiners \& Rush, 2017; Pelton, 2017; Robi, 2017; Havrilla et al, 2018; Kume \& Horbacewicz, 2018; Wolden, 2018; Oducado, Cendaña, \& Belo-Delariarte, 2019) reports how linear combinations of different cognitive outcomes predict the performance of students in various licensure examinations.

Furthermore, works particularly in the field of teacher education in the Philippines is likewise replete with predictive validity analyses (Pachejo \& Allaga, 2013; Gerundio \& Balagtas, 2014; Hena, Ballado, Dalucapas, Ubane, \& Basierto, 2014; Tarun, Gerardo, \& Tanguilig, 2014; Esmeralda \& Espinosa, 2015; Quiambao, Baking, Buenviaje, Nuqui, \& Cruz, 2015; Visco, 2015; Mayuga, 2016; Rabanal, 2016; Rudio, 2016; Dagdag, Sarmiento, Ibale, 2017; Dato-on, Ungui, Lepon, \& Del Rosario, 2017; Labastilla, 2017; Solis-Foronda, 2017; Nool, Ladia, 
Corpuz, \& Embesan, 2017; Bellen et al., 2018). The common result that ETS and GPA influence LET performance is no longer current.

The present research is related to most of the reviewed studies. It builds on the relationship between a set of independent cognitive variables and the licensure examination performance of the students. However, it is also different in a significant manner. Gaining insights both from the problem in the practice and the notions of ecological systems, this study extends the discourse to investigate the unique themes that probe the differences in the licensure examination performance of the graduates. This aspect has not been well explored in most researches dealing with the causal power of the different cognitive variables on the licensure examination performance of the graduates.

\section{Method}

\subsection{Research design}

The present work employs an embedded mixed method research design, in which the embedded nature occurs at the design level. A supportive set of information in this design is provided to a primary set of information within a larger research design. (Creswell \& Clark, 2011). For example, within the main correlation framework, the researcher may supplement a narrative strand.

There are initially two known models under this design: correlation and experimental. The present study is essentially built on these embedded design models but innovated a causal-comparative design. This main quantitative framework is embedded with qualitative information gathered through interviews. This innovation is found to meet the general purpose of this inquiry.

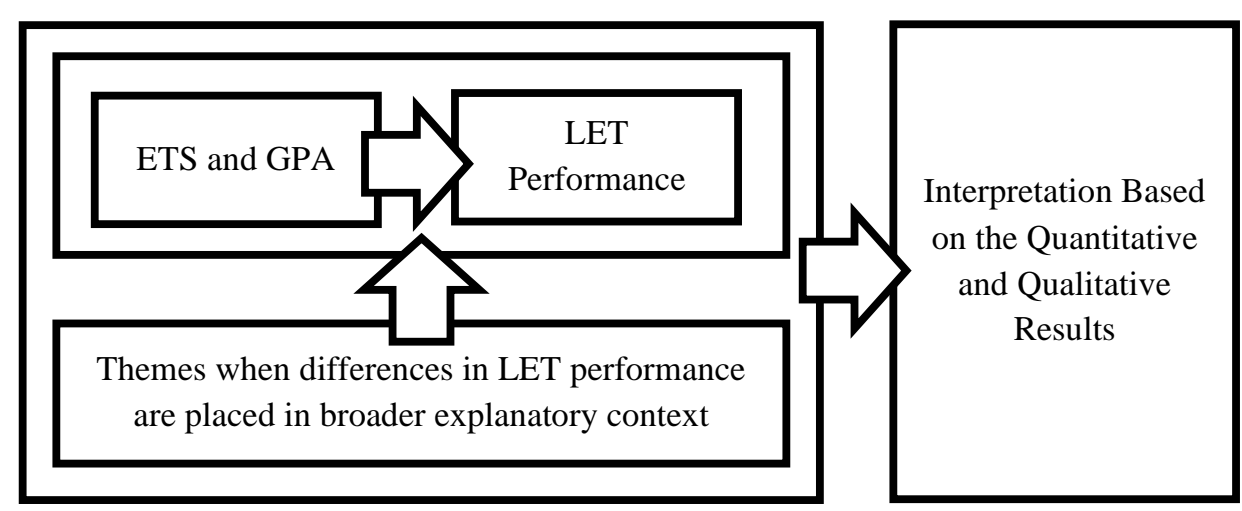

Figure 1: The embedded mixed method design of the study

\subsection{Study sample}

This research followed the cohort of students who enrolled and graduated from the BEEd Department, CoEd, MSU, GSC. There are two specific considerations for selecting the participants. First, they must have taken the system admission examination and entered the program in 2012. Second, they must have graduated from the program by completing all the course requirements to eventually take the LET in 2016. 
The population is the best sample for the study which consists of one $134(100 \%)$ officially graduated students. However, only 102 (76.12\%) of them positively responded to participate. With this initial number at hand, only $42(31.34 \%)$ were purposefully selected to be included in the final pool of the study sample. The selection was made by matching student characteristics to equally distribute them into the groups required in this research.

Moreover, from this final pool, the participants for the interview were selected by the researcher based on their exceptional cases that can help explain the differences observed. Four graduates were originally selected with the following combination of cases: conditional ETS and passed LET; conditional ETS and failed LET; passed ETS and passed LET; passed ETS and failed LET.

\subsection{Research context}

The study was conducted in the context of the BEEd Department, an academic unit that grants a degree for prospective elementary school teachers in the field. It is under the CoEd of MSU located at Fatima, GSC, South Cotabato, Philippines. It recently gained attention for garnering most of the top places in the LET including the first and second places (Estabillo, 2019).

\subsection{Data sources}

The data for this inquiry were gathered from different sources. First, the quantitative data were accessed from secondary sources upon permission. The ETS were retrieved through the online admission database while the GPA was requested from the college secretary. The ETS deals with four types of tests: aptitude, math, language, and science. The GPA is based on the weighted mean of grades from general and professional education courses. On the other hand, the certified LET ratings were obtained individually from the participants. With these quantitative data, the researcher assembled a master list that included the ETS, GPA, and LET ratings of the participants.

Moreover, the qualitative data of this paper were collected from structured interviews with selected participants. The researcher prepared an interview guide that contained common procedures and key questions to ensure each participant experience a consistent interview design. The questions specifically intended to navigate the experiences of each participant related to ETS, GPA, and LET rating. The said questions were evaluated by two colleagues of the researcher and three former students with similar characteristics as the target participants. It was done to ensure the appropriateness of the questions.

\subsection{Ethical considerations}

Following the ethical considerations in conducting a study, the participation of the graduates in this work was initially sought. A formal letter was sent to them online. It articulated the general purpose of the research, the importance of their voluntary participation, and data that it will entail. It was also stressed that confidentiality will be maintained throughout the process.

\subsection{Data collection}

The researcher followed two main stages of data collection corresponding to the two sets of data types needed for this study. These stages reflect the embedded 
nature of the mixed method design innovated specifically for the attainment of the purpose of this inquiry.

First, the researcher asked permission from the appropriate authorities and offices to obtain the ETS and GPA of the participants. When all the needed information has been furnished, the researcher organized them. Then, the data were computed, analyzed, and interpreted. The quantitative results were used as bases for framing the focus questions in the second stage.

After the interview tool has been prepared, the researcher arranged schedules with the identified participants for separate interviews. Each interview lasted on average between thirty minutes and one hour. The utterances of each participant were recorded in a master transcript. The data were coded, analyzed, and interpreted. Then, the qualitative results were structured to explain the differences uncovered initially in the causal-comparative framework.

\subsection{Data analysis}

A series of preliminary tests were performed to assess the normality and homogeneity of the data. This initial process helped the researcher determine the most suitable statistical tests to apply. Since the groups showed normal distributions and homogeneous variances, the parametric tests were found to be appropriate.

The t-test for independent samples was used to determine the difference caused by the ETS of the graduates grouped into passed and conditional categories. The test was done at 0.05 level of significance. Furthermore, the researcher carefully selected and presented interesting narrative cases of the graduates to confirm the difference caused by the ETS.

On the other hand, ANOVA was performed to answer the difference caused by the GPA of graduates grouped into low, average, and high. Tukey test further provided for the identification of the specific differences between the groups. All tests were done at 0.05 level of significance. Selected narrative cases were also presented to expound the differences caused by the GPA.

The descriptive statistics provided the mean and standard deviation for each category. All the tests were performed using SPSS version 17.

Finally, the researcher conducted a thematic analysis. The qualitative data were examined to discover the contextual insights of the participants about the differences caused by ETS and GPA on the LET performance. The utterances were analyzed, then grouped into categories and themes to explain the differences uncovered in the causal-comparative framework. The theme is the main product of this data analysis technique (Green et al., 2007).

\section{Results}

\subsection{Differences in LET performance caused by ETS}

This study first sought to find out the differences in the LET performance when the graduates are grouped according to their ETS as passed and conditional. The results are shown in Table 1. 
Table 1: LET performance by ETS

\begin{tabular}{|c|c|c|c|c|c|c|c|c|c|c|}
\hline \multirow{4}{*}{ LET } & \multicolumn{6}{|c|}{ ETS } & \multirow{2}{*}{$\begin{array}{l}95 \% \text { CI for } \\
\text { Mean } \\
\text { Difference }\end{array}$} & \multirow{2}{*}{$\mathbf{t}$} & \multirow{2}{*}{ p } & \multirow{2}{*}{ df } \\
\hline & \multicolumn{3}{|c|}{ Passed } & \multicolumn{3}{|c|}{ Conditional } & & & & \\
\hline & $\mathrm{M}$ & SD & $\mathrm{n}$ & $\mathrm{M}$ & SD & $\mathrm{n}$ & & & & \\
\hline & 80.17 & 3.01 & 21 & 76.15 & 3.21 & 21 & & & & \\
\hline
\end{tabular}

The results of the independent samples t-test show that the means of LET performance are significantly different between the graduates whose ETS is passed $(\mathrm{M}=80.17, \mathrm{SD}=3.01)$ and conditional $(\mathrm{M}=76.17, \mathrm{SD}=3.21) ; \mathrm{t}(40)=$ $4.18, p=0.00$. It can be inferred from the results that, on average, graduates with passed ETS performed better in LET than graduates with conditional ETS.

Confirming these quantitative findings with the qualitative probes, however, results seem to tell otherwise. The narrative case of Participant 1 who got passed ETS and obtained high LET performance is presented. He reasoned out that:

"My MSU entrance test score, which is a product of my high school education, did not fully contribute to my LET performance. Even though the topics in high school and the entrance test were also taught in college, however, remembering the concepts will not help that much. You need to have a good understanding of the concept to come up with the best answer in LET" (Participant 1).

For Participant 1, his ETS is a product of good education during his high school years. He further cited that his high school experiences prepared him to remember concepts which are also the skill tested in the entrance test. However, he made a distinction between the skills tested in the entrance test and the LET, saying that the entrance test entails remembering while LET needs understanding. He elaborated that taking the LET requires training in understanding concepts to be able to correctly answer the problems. Therefore, for him, ETS and his high school education by extension did not directly contribute to his LET performance.

On the other hand, Participant 2 got conditional ETS but interestingly passed the LET with higher rating compared to others who got passed ETS. Participant 2 narrated that:

"Taking the LET is different from taking the entrance test. I got a low score during the entrance test because I was not able to review due to being busy having different activities way back in our high school days. On the other hand, takers in the LET are given ample time of review and even the CoEd helped through the provision of review materials" (Participant 2).

Based on the statements of Participant 2, ETS is not an indication of LET performance. His low score in the entrance test, as he enlightened, was caused by a lack of preparation before the entrance test, which subsequently resulted in him obtaining conditional ETS. It can be implied that his ETS is not a reflection 
of his real performance at that time and he could have gained passed ETS. He claimed that by the time he would take the LET, he had enough time to prepare through review. It is interesting to note that he performed in the LET with a higher score compared to most of those who got passed ETS.

Lastly, Participant 3 got conditional ETS and obtained low LET performance. She told in the interview that:

"No, because in the LET, my mindset is already different from the admission examination that I took. I got low scores on my admission examination because at that time when I took it, our family had a big problem and it affected my concentration. But now I already have the confidence that I can pass the LET with faith" (Participant 3).

As can be discerned from the statements of Participant 3, she does not relate her low ETS to her eventual low LET performance. When she took the entrance test, she cited personal reasons such as family problems that affected her concentration, which resulted in her low ETS. This implies that her ETS does not reflect her ability to perform well in the LET. Although she got a low score in the LET, she claimed to have later gained knowledge to perform well.

\subsection{Differences in LET performance caused by GPA}

This study also sought to find out the differences in the LET performance when the graduates are grouped according to their GPA as high, average, and low categories. The results are shown in Table 2.

Table 2: LET performance by GPA

\begin{tabular}{|c|c|c|c|c|c|c|c|}
\hline \multirow{5}{*}{ LET } & \multicolumn{5}{|c|}{ GPA } & \multicolumn{2}{|c|}{ Tukey Comparisons } \\
\hline & Categories & M & SD & $\mathrm{n}$ & $\mathrm{p}$ & High & Average \\
\hline & High & 80.72 & 2.28 & 11 & \multirow{3}{*}{$.006^{*}$} & & \\
\hline & Average & 78.15 & 4.00 & 17 & & .126 & \\
\hline & Low & 76.15 & 3.04 & 14 & & $.004^{*}$ & .228 \\
\hline
\end{tabular}

A one-way ANOVA was conducted to compare the significant difference in the first time LET performance of graduates grouped according to high, average, and low GPA categories. The results showed that there is a significant difference in the LET performance of the graduates for the three categories $(p=0.006)$. Tukey test further indicated that the LET performance mean score for graduates with high GPA $(\mathrm{M}=80.72, \mathrm{SD}=2.28)$ was significantly different from the students with low GPA $(\mathrm{M}=76.15, \mathrm{SD}=3.04), \mathrm{p}=0.004$. On the other hand, the LET performance of the graduates with average GPA $(\mathrm{M}=78.15, \mathrm{SD}=4.00)$ was not significantly different from graduates with high GPA, $p=.126$, and graduates with low GPA, $\mathrm{p}=.228$.

Probing these quantitative findings to the qualitative findings, results complement each other. For example, Participant 1 stated about GPA that: 
"My GPA reflects the way our professors urged us to study, asked us baffling questions, and motivated us to be very critical in every information or situation given. They taught us to learn things independently which helped me in the LET because most of the questions in the LET would measure your decision making in the real scenario or the actual classroom" (Participant 1).

Participant 1 described that the GPA and its contributory factors helped him pass the LET. These contributory factors are mostly the ways he was trained during his college years. He cited these factors as being urged by his professors to study well, motivated to read beyond what is shown, asked critical questions that he does not have an idea, and critical in analyzing given situations. These factors helped him answer the questions in the LET, which according to him, required a deep understanding and critical thinking about given actual teaching situations.

Participant 2 likewise supported the result that GPA made a difference. He detailed his context that:

"The main factor that helped me or challenged me to obtain a good GPA and to pass all of my subjects during my college years in MSU is that my other siblings are all MSU graduates and all of them are professionals. It challenged me in a way that I should also graduate. I cannot find a great school to which I only pay 3000 pesos in a semester. I might as well give justice to what I pay and have a good GPA. Yes, GPA made a difference in my performance in the LET" (Participant 2).

For Participant 2, GPA is an indicator of passing the LET. Looking further into the driving force of his good GPA in college, it can be revealed that indirect family pressure prompted him to academically achieve higher and eventually pass the LET. He said that his siblings are all graduates of the same state university where he was also studying and all of them have become professionals. These forms of expectations challenged him in a way that he saw the expectation to graduate also from the same university and become a licensed professional teacher.

Moreover, Participant 3 shared a very personal case. She recounted experiences related to GPA by saying that:

"I believe that my GPA, a reflection of my 5 years of studying at MSU, is enough for me to pass the LET. One of the reasons that inspired me to strive for a good GPA is that I wanted to show to people who underestimated me that I can graduate in the university. I admit that since when I was a child, I used to be asthmatic. The people in my surrounding knows my past situation well, which is the reason why they underestimated me when I entered university. They said that I cannot graduate because of my situation, that I chose a school that does not fit me because the buildings are scattered. It is very hot, very dusty, plus the fact that my father died. People judged me easily and it hurt a lot. 
But then I did not care what the people said. I continued my dream to graduate with a degree" (Participant 3).

Participant 3 believed that her GPA is a factor that helped her in the LET. But exploring deeper into her motivation, she disclosed that her desire to prove her worth to other people inspired her to study well in college and pass the LET. She expressed that many people underestimated her capabilities to finish college because she used to be frail and people thought she will not survive given the university environment. However, she used those experiences as inspiration to reach her ultimate dream to graduate from college and pass the licensure examination.

\subsection{Themes when differences in LET performance are explained}

This study ultimately intended to probe the themes that explain the differences in the LET performance of the graduates when placed in a broader context. The results are shown in Table 3.

Table 3: Themes when differences in LET performance are explained

\begin{tabular}{|c|c|c|}
\hline Codes & Categories & Themes \\
\hline $\begin{array}{l}\text { Even the CoEd helped through the provision } \\
\text { of review materials, especially in the } \\
\text { professional education courses. }\end{array}$ & $\begin{array}{l}\text { Reviewer from the } \\
\text { college as a resource } \\
\text { material }\end{array}$ & \multirow[t]{3}{*}{$\begin{array}{l}\text { Access to } \\
\text { review } \\
\text { materials }\end{array}$} \\
\hline $\begin{array}{l}\text { Some of the questions in the LET are very } \\
\text { familiar to me because some of them are in } \\
\text { the reviewers that I read. }\end{array}$ & $\begin{array}{l}\text { Reviewers to } \\
\text { familiarize with the } \\
\text { types of questions }\end{array}$ & \\
\hline $\begin{array}{l}\text { I read the different reviewers as much as I } \\
\text { could and then I answered their test } \\
\text { questions. }\end{array}$ & $\begin{array}{l}\text { Reviewers as sources } \\
\text { of test contents and } \\
\text { questions }\end{array}$ & \\
\hline $\begin{array}{l}\text { I just made sure that I have a deeper } \\
\text { understanding of the concepts in education } \\
\text { and did not memorize everything. }\end{array}$ & $\begin{array}{l}\text { Awareness of relevant } \\
\text { thinking skill for the } \\
\text { examination }\end{array}$ & \multirow[t]{3}{*}{$\begin{array}{l}\text { Metacognitive } \\
\text { strategies }\end{array}$} \\
\hline $\begin{array}{l}\text { The only thing that I relied on was the } \\
\text { lessons that were taught particularly those } \\
\text { topics in the teaching profession. }\end{array}$ & $\begin{array}{l}\text { Selection of } \\
\text { appropriate contents } \\
\text { for review }\end{array}$ & \\
\hline $\begin{array}{l}\text { I check it myself if I got a high or low score } \\
\text { and see to it that I give time to study the } \\
\text { mistakes that I made. }\end{array}$ & $\begin{array}{l}\text { Internal monitoring of } \\
\text { own performance in } \\
\text { the test }\end{array}$ & \\
\hline $\begin{array}{l}\text { My other siblings are all MSU graduates and } \\
\text { all of them are professionals. It challenged me } \\
\text { in a way that I should also graduate. }\end{array}$ & $\begin{array}{l}\text { Positive pressure from } \\
\text { indirect family } \\
\text { experiences }\end{array}$ & \multirow[t]{2}{*}{$\begin{array}{l}\text { Motivational } \\
\text { experiences }\end{array}$} \\
\hline $\begin{array}{l}\text { I decided to myself that I will use those people } \\
\text { who looked me down as a motivation to strive } \\
\text { hard, to achieve all the dreams in my life. }\end{array}$ & $\begin{array}{l}\text { Inspiration from } \\
\text { undesirable external } \\
\text { experiences }\end{array}$ & \\
\hline $\begin{array}{l}\text { Aside from the learning, you need to have the } \\
\text { confidence in yourself that you can indeed } \\
\text { conquer the examination. }\end{array}$ & $\begin{array}{l}\text { Confidence that one } \\
\text { can pass the } \\
\text { examination }\end{array}$ & $\begin{array}{l}\text { Efficacy to } \\
\text { succeed }\end{array}$ \\
\hline
\end{tabular}




\begin{tabular}{|l|l|l|}
\hline $\begin{array}{l}\text { I always set in my mind that I must pass the } \\
\text { licensure examination for me to become an } \\
\text { officially certified teacher. }\end{array}$ & $\begin{array}{l}\text { Conditioning of the } \\
\text { mind to pass the } \\
\text { examination }\end{array}$ & \\
\hline
\end{tabular}

Thematic analysis was used to analyze the utterances of the participants. This process involved the generation of codes, categories, and themes. The following themes emerged from the analysis:

Theme 1: Access to review materials. The graduates have access to different review materials including the one developed by their department. Other reviewers were from review centers and stores. These review materials helped them become exposed to different types of questions that are like the ones in the LET. The reviewers also usually have practice tests. It assisted the participants in honing their skills in taking the test.

Theme 2: Metacognitive strategies. Some thinking strategies were used by the participants to train their minds in answering LET questions. They prepared their mind by familiarizing with the kind of questions asked in the LET which required application rather than just knowledge. They were also selective with the type of topics for focus in the review. They monitored their test performance. They took mock tests by themselves, checked where they went wrong and studied it to improve.

Theme 3: Motivational experiences. An interesting theme as revealed by the participants is their personal motivational experiences which they used as inspiration to succeed in the LET. The participants mentioned personal experiences such as unspoken pressure brought by family achievement and personal struggle against the negative perceptions of other people around. What made these experiences more interesting is the fact that they used the circumstances as positive motivations to succeed in their studies and the LET.

Theme 4: Efficacy to succeed. The graduates also expressed a form of efficacy to succeed, a strong conviction in themselves that they will pass the LET. They cited that aside from what they have learned, they conditioned their minds that they should succeed to reach their goals. They developed a kind of confidence in themselves, claiming optimistically that they will pass the LET.

\section{Discussion}

The initial quantitative result of this study is not surprising. It supports the general notion about the influence of the ETS on the board examination performance. For example, the results of the research of Moniyung (2015) demonstrated that a point increase in ETS increases the odds of being successful in the nursing licensure examination by almost five times. When it comes to the field of teacher education, the result of this paper also coincides with the results of Dagdag et al. (2017) which accounted for a medium influence of ETS on the general education and professional education components of the LET.

Amidst the extensive discourse in other numerous quantitative studies, however, the contextual reasons for the differences in the licensure examination performance of the students based on ETS have not been well explored. It is 
particularly interesting that, in the qualitative probes of this study, ETS did not consistently appear to be a contributor to the LET performance.

A participant articulated this dissociation between ETS and LET by saying that ETS and LET are different. He expounded that ETS measures stock knowledge while LET mostly requires the application of knowledge in educational situations. This way, ETS did not influence his LET performance. Feeley, Williams, and Wise (2005) critiqued the validity of some admission tests in predicting the future performance of the students. They pointed out that some of the admission tests do not measure higher thinking abilities such as application of knowledge which is usually tested in licensure examinations.

The other participants justified that they have matured in the process such that ETS was not significant by the time they took the LET. The concept of maturation is a learning process characterized by an increase of competencies. It enables a person to perform something that he or she cannot previously perform (Thakker, 2019). Thus, based on the premise of the participants, maturation has control in the possibility that ETS has no causal role in the LET performance of the participants.

Moreover, the result of this study when it comes to the influence of GPA on the LET performance is consistent with the trends found in the previous studies. Hence, for instance, Bayliss et al. (2017) determined the GPA to be the greatest predictor of the first pass rate on the national physical therapy examination. This result is also not new in the field of teacher education. Labastilla (2017) uncovered a substantial relationship between GPA and the ratings of the students in the professional education component in the LET.

On the other hand, qualitative studies are still to be desired with regards to the association between the GPA and success in licensure examinations. The qualitative result of the present inquiry offered interesting narratives of GPA as a predictor variable that is more than just a number. The participants disclosed that GPA reflects the different experiences that shaped their motivations to earn a good GPA and perform in the LET. These experiences consist of the practices of their professors, expectations of their families, and behaviors of other individuals in the environment.

Such qualitative result elucidated by the participants appears to be captured in the psychological construct known as motivational climate. Based on the early works of Ames (1992), the motivational climate is a social situation in which significant others like teachers, coaches, and parents facilitate motivational achievement. It occurs through the expectations, values, and behaviors demonstrated to the students (Weigand, Carr, Petherick, \& Taylor, 2001). This construct precisely mirrors the premises indicated by the participants.

Finally, this study significantly proposes evidence about the themes that contextually explain the differences caused by ETS and GPA on the LET performance. The participants conveyed unique themes such as access to review materials, metacognitive strategies, motivational experiences, and efficacy to succeed. These themes emulate the nature of human performance as a result of diverse systems, interactions, and factors in the environment. 
The basic notions of ecological systems (Bronfenbrenner, 1979) can be used to reinforce the themes that underpin the differences in the LET performance of the graduates. The ecological systems theory deals with the biological, emotional, social, and cultural aspects of the environment. It conceives that human interactions, institutions, and systems have a profound impact on the development of a person. The themes illustrate the graduates as part of their selves, families, and institutions. Their interactions with other people, connections with institutions in education, and their relationships with the entire system provided them the resources, strategies, and experiences. These all contributed to their LET performance.

\section{Conclusion}

This study was guided by its general purpose. It attempted to probe the differences caused by selected cognitive variables such as ETS and GPA on the LET performance of the graduates.

It was disclosed that the ETS of the graduates grouped as passed and conditional cause a significant difference in the LET performance. However, this quantitative result did not appear to be corroborated in the qualitative result. The participants clarified that ETS and LET are two different tests measuring different knowledge types and levels. They must have also matured in between ETS and LET such that ETS did not define their performance by the time they took the LET.

This current research offers an alternative interest to the readers regarding the absolute validity of ETS as a predictor of LET performance. The result of this study drew different quantitative and qualitative outcomes. It can be maintained that ETS is still an essential admission criterion. However, it should be underscored that comprehensive screening approaches require two or more valid instruments. Some emerging tools recommended in education are teaching aptitude tests and multiple mini interviews. These instruments qualitatively appraise students in other important aspects that may be predictive of future performance in the licensure examination.

Moreover, this study revealed that the GPA of the graduates grouped as high, average, and low causes a significant difference in the LET performance. The GPA further proved to be more than just a number. It is mediated by the motivational climate that forms an important factor in the LET performance of the graduates. The participants indicated that the practices of their professors, expectations of their families, and behaviors of other individuals shape their motivation to obtain a good GPA and ultimately pass the LET.

This scholarly work allows educators to make informed decisions when dealing with students concerning their GPA and future LET performance. The result provides a set of tentative notions that map students in terms of their GPA, a variable that is found to be sensitive to motivational climate. There is a need to prospectively validate this convoluted result to be able to develop a comprehensive and responsive intervention program that will improve the performance trajectory of the students in the future licensure examination. 
Lastly, following an embedded mixed method research design, this study effectually unearthed essential themes that explain the differences caused by the ETS and GPA on the performance of the graduates in the LET. These themes include access to review materials, metacognitive strategies, motivational experiences, and efficacy to succeed.

This innovation paper provides a wider and newer insight about the covert aspects that underpin the differences in the performance of the graduates in the LET. The result reveals themes that are not typically given attention in the tradition of largely quantitative works. Thus, the qualitative aspect of the study is proposed to be replicated as an extension of the typically statistical analysis of the relationship between the cognitive variables and licensure examination performance of the graduates.

There are also restrictions encountered in this study. It was principally conducted in a single research venue. The selected cognitive variables were the ETS and GPA only. Though the tests of normality and homogeneity were satisfied, the sample was still relatively dismal. The conduct especially of the qualitative portion was constrained by the fact that it only included three cases from the original four cases that represent the maximum variation of possible cases that can be included. Hence, the conclusions drawn in this study should be carefully applied with consideration to the current context.

\section{References}

Ames C. (1992). Achievement goals, motivational climate, and motivational processes. In G. C. Roberts (Ed.), Motivation in sport and exercise (pp. 161-176). Champaign, IL: Human Kinetics.

Bayliss J., Thomas R. M., \& Eifert-Mangine M. (2017). Pilot study: What measures predict the first time pass rate on the National Physical Therapy Examination? The Internet Journal of Allied Health Sciences and Practice, 15(4), 1-12. Retrieved from https://nsuworks.nova.edu

Bellen, J., Abela, R., \& Truya, R. (2017). Academic Achievement as Predictor in the Performance of Licensure Examination for Teachers. Asia Pacific Journal of Education, Arts, and Sciences, 5(1), 77-81. Retrieved from http://apjeas.apjmr.com/wp-content/uploads/2018/02/APJEAS2018.5.1.09.pdf

Bennett, M., Bormann, L., Lovan, S., \& Cobb, B. (2016). Preadmission predictors of student success in a Baccalaureate of Science in Nursing program. Journal of Nursing Regulation, 7(3), 11-18. https:/ / doi.org/10.1016/S2155-8256(16)32315-8

Bronfenbrenner, U. (1979). The ecology of human development: Experiments by nature and design. Cambridge, MA: Harvard University Press.

Cameron, A., MacKeigan, L., Mitsakakis, N., \& Pugsley, J. (2017). Multiple miniinterview predictive validity for performance on a pharmacy licensing $\begin{array}{llll}\text { examination. } \quad \text { Medical } & \text { 5ducation, }\end{array}$ https://doi.org/10.1111/medu.13222

Commission on Higher Education. (2017). Professional Regulation Commission national passing percentage by discipline. Manila, Philippines: Author.

Cook C., Engelhard C., Landry M., \& McCallum C. (2015). Modifiable variables in physical therapy education programs associated with first-time and three-year National Physical Therapy Examination pass rates in the United States. Journal of 
Educational Evaluation for Health Professions, 1(44), 1-8. http://dx.doi.org/10.3352/jeehp.2015.12.44.

Creswell, J. W. \& Clark, V. L. P. (2011). Designing and conducting mixed methods research ( $2^{\text {nd }}$ ed.). Thousand Oaks, CA: Sage.

Culpepper, D., \& Killion, L. (2016). It's not me, it's you: The disconnect of physical education teachers to physical activity in the gym. Sports, 3(4), 302-311. https://doi.org/10.3390/sports3040302

Dagdag, J. D., Sarmiento, C. S., \& Ibale, J. C. (2017). Examining the factors of Licensure Examination for Teachers performance for program strategy enhancement. Asia Pacific Journal of Multidisciplinary Research, 5(4), 34-39. Retrieved from www.apjmr.com

Darling, N. (2007) Ecological Systems Theory: The person in the center of the circles. Research in Human Development, 4(3), 203-217. https:// doi.org/10.1080/15427600701663023.

Dato-on, R. P., Ungui, R. M., Lepon, L. S., \& Del Rosario, J. D. (2017). Academic and Licensure Examination for Teachers (LET) performances of the teacher education students of the CTU North Campuses. Proceedings of the 10th International Conference on Arts, Social Sciences, Humanities, and Interdisciplinary Studies (pp. 61-65). Manila, Philippines. Retrieved from https://uruae.org/siteadmin/upload/UH1217417.pdf

Eriksson, M., Ghazinour, M., \& Hammarstrom, A. (2018). Different uses of Bronfenbrenner's ecological theory in public mental health research: what is their value for guiding public mental health policy and practice? Social Theory $\mathcal{E}$ Health, 16(4), 414-433. https:/ / doi.org/10.1057/s41285-018-0065-6

Esmeralda, A. B. \& Espinosa, J. P. (2015). Teacher education graduates' performance as a predictor of Licensure Examination for Teachers' results. JPAIR Multidisciplinary Research, 21(1). https://doi.org/10.7719/jpair.v21i1.330

Estabillo, A. (2019, December 2). MSU-GenSan produces record 17 LET topnotchers. Philippine News Agency. Retrieved from https://www.pna.gov.ph/articles/1087648

Feeley, T. H., Williams, V. M., \& Wise, T. J. (2007). Testing the predictive validity of the GRE on communication graduate student success: A case study at University at Buffalo. Communication Quarterly, 53(2), 229-245. doi:10.1080/ 01463370500090209

Gerundio, M. G., \& Balagtas, M. U. (2014). Exploring formula for success in the teachers' licensure examination in the Philippines. Educational Measurement and Evaluation Review, 5(1), 104-117. Retrieved from https:/ / ejournals.ph/article.php?id=6548

Green J., Willis, K., Hughes, E., Small, R., Welch, N., Gibbs, L., \& Daly, J. (2007). Generating best evidence from qualitative research: the role of data analysis. Australian and New Zealand Journal of Public Health, 31(6), 545-50. https: //dx.doi.org/10.1111/j.1753- 6405.2007.00141.x

Gresham, B. B., Thompson, M., Luedtke-Hoffman, K., \& Tietze, M.F. (2015). Institutional and Program Factors Predict Physical Therapist Assistant Program Graduation Rate and Licensure Examination Pass Rate. Physical Therapy Education, 29(4), 2736. https://doi.org/10.1097/00001416-201529040-00005

Gullo, C. A., McCarthy, M. J., Shapiro, J. I., \& Miller, B. L. (2015). Predicting medical student success on licensure exams. Medical Science Education, 25(4), 447-453. https://doi.org/10.1007/s40670-015-0179-6

Havrilla, E., Zbegner, B., \& Victor, J. (2018). Exploring predictors of NCLEX-RN success: One school's search for excellence. Journal of Nursing Education, 57(9), 554-556. https:// doi.org/10.3928/01484834-20180815-08 
Hegmann T., Roscoe M., \& Statler, M. (2015). Reliability and validity of PAEA End of Rotation TM examination scores for predicting performance on the Physician Assistant National Certification Examination. The Journal of Physician Assistant Education, 26(4), 187-192. https://doi.org/10.1097/jpa.0000000000000044

Hena, R., Ballado, R., Dalucapas, M., Ubane, S., \& Basierto, R. (2014). Variates of the performance of teacher education graduates in the Licensure Examination for Teachers (LET). International Journal of Interdisciplinary Research and Innovations, 2(4), 157-163.

Huhn, K., \& Parrott, J. S. (2017). Exploration of relationships among the health sciences reasoning test, the national physical therapy licensing examination, and cognitive admission variables. Journal of Physical Therapy Education, 31(1), 7-13. https://doi.org/10.1097/00001416-201731010-00004

Ingrassia, J. M. (2016). Successful admission criteria to predict academic and clinical success in entry-level radiography programs. Radiologic Technology, 87(5), 502510. Retrieved from https://www.ncbi.nlm.nih.gov/pubmed/27146174

Kaddoura, M. A., Flint, E. P., Van Dyke, O., Yang, Q., \& Chiang, L. (2017). Academic and demographic predictors of NCLEX-RN pass rates in first- and second- degree accelerated BSN programs. Journal of Professional Nursing, 33(3), 229-240. doi:10.1016/j.profnurs.2016.09.005

Kidder, K. R. (2015). Predictive factors of NCLEX-RN success (Doctoral dissertation, Carlow University, Pittsburgh, Pennsylvania). Retrieved from http:// proxy.lib.duke.edu/login?url=http:// search.proquest.com/docview/16 73190131? accountid $=10598$

Knowles, K. T., Plake, B. S., Robinson, D. Z., \& Mitchell, K. J. (Eds.). (2001). Testing teacher candidates: The role of licensure tests in improving teacher quality. Atlanta, Georgia: National Academies Press.

Kume, V., \& Horbacewicz, R. (2018). Predictors of Physical Therapy Academic and NPTE Licensure Performance. Health Professions Education, 5(3), 185-193. https://doi.org/10.1016/j.hpe.2018.06.004

Labastilla, I. S. (2017). Admission factors associated with the academic and Licensure Examination for Teachers performances of the graduates from Mindanao State University-Maigo School of Arts and Trades. International Journal of Management and Applied Science, 3(9), 34-38. https://doi.org/10.2139/ssrn.3169642

Mayuga, V. (2016). Field study courses and internship as practical work approach: Determinants of LET performance. Proceedings of the 3rd International Conference on Language, Innovation, Culture, and Education (pp. 74-86). Retrieved from https://www.semanticscholar.org/paper/Field-Study-Coursesand-Internship-as-Practical-of-

Mayuga/5a40e75fceccdf6dbb8edd9b7b43957eba0e1753

Meiners, K. M. \& Rush, D. K. (2017). Clinical Performance and Admission Variables as Predictors of Passage of the National Physical Therapy Examination. Journal of Allied Health, 46(3), 164-170. Retrieved https://www.ncbi.nlm.nih.gov/pubmed/28889166

Moniyung, C. (2015). Academic and non-academic variables as predictors of NCLEX- RN success among traditional associate degree students at Southern Adventist University (Doctoral dissertation, Andrews University, Berrien Springs, Michigan). Retrieved from https://digitalcommons.andrews.edu/dissertations/1571

Nool, N. R., Ladia, M. A. P., Corpuz, N. B., \& Embesan, S. A. (2017). Exploring the validity of TSU College Admission Test in predicting graduates' LET Performance. Paper presented at the 2017 Year-End In-House Review of Completed Researches, Tarlac State University, Tarlac City, Philippines. Retrieved from 
https://www.academia.edu/42318279/Exploring_the_Validity_of_TSU_Colleg e_Admission_Test_in_Predicting_Graduates_LET_Performance_2017_

Oducado, R. M., Cendaña, D. P., \& Belo-Delariarte, R. G. (2019). Institutional competency assessment and other factors influencing the Nurse Licensure Examination. International Journal of Scientific \& Technology Research, 8(12), 268270. Retrieved from https:// sigma.nursingrepository.org/handle/10755/19365

Pachejo, S., \& Allaga, W. (2013). Academic predictors of the licensure examination for teachers' performance of the Rizal Technological University teacher education graduates. International Journal of Educational Research and Technology, 4(4), 31-40. Retrieved from http://www.soeagra.com/ijert/ijertdecember2013/7.pdf

Pelton, S. B. (2017). Correlation of University Comprehensive and National Certification Exam Scores for Medical Laboratory Science Students. American Society for Clinical Laboratory Science, $30 \quad$ (4), 240-246. https://doi.org/10.29074/ascls.30.4.240

Philippine Teachers Professionalization Act of 1994 (1994, December 16). Retrieved from https://www.pcw.gov.ph/law/republic-act-7836

Pitter, G. W., Lanham, C. H., \& McGalliard, D. (1997). Licensure examination results as outcome indicators: Issues and challenges: Report presented to the State University System of Florida. Retrieved from https:/ / files.eric.ed.gov

Quiambao, D., Baking, E., Buenviaje, L., Nuqui, A., \& Cruz, R. (2015). Predictors of board exam performance of the DHVTSU college of education graduates. Journal of Business \& Management Studies, 1(1), 1-4. http:/ / advancejournals.org/Journal-ofBusiness-and-Management-Studies/article/predictors-of-board-examperformance-of-the-dhvtsu-college-of-education-graduates/

Rabanal, G. (2016). Academic achievement and LET performance of the bachelor of elementary education graduates, University of Northern Philippines. International Journal of Scientific and Research Publications, 6(6), 455, 461. Retrieved from https://www.ijsrp.org

Robi, Y. S. (2017). Diploma program graduates' CGPA as predictor of success in the teachers' professional licensing written exam result with gender analysis: The case of 2014/15 diploma graduates of KUC. International Journal of Educational Reform, 26(4), 321-335. https://doi.org/10.1177/105678791702600405

Rojas-Drummond, S. M. (2016). Explaining literacy development from a bioecological systems framework: Affordances and challenges. Human Development, 59(4),188194. https://doi.org/10.1159/000449263

Rudio, V. O. (2016). Performance of Teacher Education Graduates, DMMMSU-NLUC, Philippines in the Licensure Examination CY 2011 to 2013. International Journal of Educational Science and Research, 6(3), 1-16. Retrieved from https://ssrn.com/abstract $=2838142$

Solis-Foronda, M. (2017). Predictors of Licensure Examination for Teachers (LET) performance: A mediation analysis. Proceedings of the International Conference on Digital Technology in Education (pp. 74-88). Taipei, Taiwan. https://doi.org/10.1145/3134847.3134863

Tarun, M., Gerardo, B. D., \& Tanguilig, B.T. (2014). Generating licensure examination performance models using PART and JRip classifiers: A data mining application in education. Iranian Journal of Chemistry and Chemical Engineering, 3(3), 202-207. doi:10.7763/IJCCE.2014.V3.320

Thakker, P. (2019, June 20). Maturation - Definition and types of maturation. Toppr Bytes [Blog post]. Retrieved from https://www.toppr.com/bytes/maturation/ 
Tzeng, Y. F., \& Gau, B. S. (2012). Nursing care of a school-age child with asthma: an ecological system theory approach. $\mathrm{Hu} \mathrm{Li} \mathrm{Za} \mathrm{Zhi}$, 59(1), 96-103. Retrieved from https://www.ncbi.nlm.nih.gov/pubmed/22314656

Visco, D. (2015). Predictors of performance in the licensure examination for teachers of the graduates of higher education institutions in Abra. International Journal of Management Research and Business Strategy, 4(1), 181-191. Retrieved from https://www.ijmrbs.org

Walker, T. (2016, March). Ecological systems theory: Using spheres of influence to support small-unit climate and training: Report presented to the US Army Institute. https://doi.org/10.21236/ad1009046

Weigand, D., Carr, S., Petherick, C., \& Taylor, A. (2001) Motivational climate in sport and physical education: The role of significant others. European Journal of Sport Science, 1(4), 1-13. https://dx.doi.org/10.1080/17461390100071402

Wolden, M. J. (2018). Predicting success on the National Physical Therapy Examination: A systematic review of the literature and random effects meta-analysis (Doctoral dissertation, North Dakota State University, North Dakota, USA). Retrieved from https://library.ndsu.edu/ir/handle/10365/27895 